\title{
Political Bargaining Chips: Republican Internees in Northern Ireland
}

\section{2-1975}

\section{Tony Craig** and Martin McCleery ${ }^{\mathrm{b}}$}

\author{
${ }^{a}$ Staffordshire University, UK; ${ }^{b}$ Independent Scholar
}

*Contact: t.craig@staffs.ac.uk

\begin{abstract}
From March 1972 until internment itself was eventually abandoned in December 1975 successive Secretaries of State for Northern Ireland used their powers to arrest and release republican internees. This article demonstrates that several factors contributed to the policy of controlling the arrests and releases of internees, and that the most important was not negotiations with the Provisional IRA (PIRA) but the need to encourage the engagement of moderate nationalists in an emerging political process. Although the story of internment is often exclusively seen in the narrower narratives of paramilitary historiography and the later 'prison war'. This article adopts a broader contextual approach in which both moderate nationalist, and to a lesser extent, unionist concerns over arrests and releases are considered. In doing so, this work resituates the gradual ending of internment at the heart of the mainstream political discussions in Northern Ireland in the 1970s. The article also contends that this controlled use of internment as a political strategy ultimately proved to be successful for the British government in achieving their desired objectives.
\end{abstract}

\section{Introduction}

The conflict in Northern Ireland (widely known as The Troubles) arguably began in the Autumn of 1968 when (unionist) state-led resistance to a (largely nationalist) civil rights campaign of protests began to interact with the long-established sectarian and political divisions over the constitutional status of the province. Sporadic rioting increased in both duration and ferocity in the summer of 1969 until the resources of the local police were exhausted and the devolved Northern Ireland government sought help from the national government in London. The deployment of the British Army, ostensibly to aid the Northern Ireland authorities, helped create conditions where the once marginalised Irish Republican Army (IRA) could re-emerge, using the very presence of the British Army to prove their 
argument that British rule in Northern Ireland had an unjust colonial basis. ${ }^{1}$ The conflict was not simply between Irish Republicans and the British Security Forces however, and loyalist paramilitaries contributed significantly to the violent disorder that continued until the Good Friday Agreement was reached in 1998. Being part Counter Insurgency, part peacekeeping and part peace building, the British response to the Northern Ireland conflict was always complicated by Northern Ireland's constitutional position as a full part of the United Kingdom which arguably limited the amount of coercion and physical force they could use. No more so was this the case than when the policy of interning Irish Republican paramilitary suspects without trial began in August 1971. Rather than ending the violence, the effective suspension of the right to a trial for those selected for internment immediately led to the radicalisation of whole sections of the minority nationalist community in Northern Ireland and the vilification of Britain's policies both at home and abroad. Once it was introduced, however embarrassing it was, internment proved exceedingly difficult to get rid of and remained in place until the end of 1975 when a whole series of policy changes attempted more widely to end the association of the conflict with colonial insurrection and reframe the conflict as violent criminality. Known as 'normalisation', 'criminalisation' and 'ulsterisation' the policies effectively gave the lead role in counter terrorism back to the local police and the locally raised army regiment (Ulster Defence Regiment (UDR)) and adapted the legal system so as to obtain more convictions of terrorist suspects. These changes ended the perceived need for internment without trial of terrorist suspects who were now to be considered as simply criminals in organised gangs rather than insurgents engaged in combat. In doing so however the British had to release all internees they could not convict, however deeply involved in IRA operations they believed them to be.

The ending of internment also occurred in the midst of two parallel sets of political talks, the first, secret talks in the context of the IRA's 1975 ceasefire; the second, public negotiations 
with the mainstream political parties known as the Constitutional Convention. Though amnesties for the possession of weapons and IRA membership were granted in this period, this article argues that the associated arrest and release of prisoners was as much a part of the attempt to maintain moderate nationalist support for any proposed political arrangements as it was in achieving an IRA cessation of violence, as indeed had been the case since 1972.

This article will employ a wider definition of amnesty which is not restricted solely to the release of existing prisoners, but which also bars criminal prosecution against individuals or categories of individuals for offenses they had not been detained for when the amnesty began. ${ }^{2}$ Not arresting these individuals is implicit in this wider definition also. In Northern Ireland, the United Kingdom government has tended not to use the term 'amnesty' in any public discussion of such policies (and only rarely is the term used privately). Traditionally the UK government has preferred more specific and limited terms to describe policy changes made in response to periods of IRA inaction or ceasefire. Since the late 1990s of course the UK has released prisoners convicted of terrorist offenses in Northern Ireland 'on licence' and has more recently provided notices to 'On The Run' suspects that they were no longer under active investigation for crimes they had previously been suspected of (The Guardian, May 8, 2014). Although both these examples constitute forms of amnesty to some extent (with the continued freedom of the individuals concerned being largely in the hands of the organisations they were members of) the embarrassing potential of calling these acts amnesty, or of linking them to a wider policy aimed at completing a peace process, has limited their public discussion. This has been particularly true when these policies come into conflict with the continued campaigns for justice from victims of the violence and their families in both Britain and Ireland, North and South. 
Nevertheless, both in the 1970s and after 1994, the release of paramilitary prisoners in Northern Ireland can be seen as conforming to both a form of 'constructive' amnesty (with the intention to end violence and create trust in an emerging peace process), as well as a 'contingent' amnesty (where the purpose of prisoner release serves a narrower strategic purpose than communicating peaceful intent to the opposing organisation alone and can be used to play reciprocal politics in tandem with negotiations elsewhere). Furthermore, there are also elements in the way that the internment regime ended in Northern Ireland of what can be defined as 'destructive' amnesty, particularly with the attempts to isolate hard-core militants; singling them out for future, harsher treatment and/or longer periods of incarceration should their organisations return to their violent campaigns.

\section{The 1969 Amnesty}

In 1969 the then devolved Northern Ireland government had fewer reservations regarding the long-term effects of using the term amnesty but, due to the nature of the conflict at that point, the vast majority of the beneficiaries of their amnesty had committed criminal acts far short of any reasonable definition of terrorism. In fact, the only major terrorist attack until that point - the loyalist Ulster Volunteer Force's (UVF) bombing of Belfast's water supply in March and April 1969 - was specifically excluded from the amnesty when it was announced. The 1969 amnesty was permanent and covered both nationalist and unionist offenders as well as the security forces. ${ }^{3}$ Amnesty in 1969 was most controversial when it came to the release of the prominent ultra-unionist Rev. Ian Paisley - later founder of the Democratic Unionist Party (DUP) and of course Northern Ireland First Minister 2007-2008 - as, then Northern Ireland Prime Minister, James Chichester-Clark argued privately that 'if the Paisley faction returned to the streets, the entire story of street agitation might be repeated. ${ }^{, 4}$ Although Paisley's release was still granted, the 1969 amnesty provided what Chichester-Clark had intended, a breathing space between the civil rights protestors and the government. However, 
intercommunal tensions had already been ignited and more sectarian violence meant that the overall effect of the 1969 amnesty was to ease tensions for a matter of weeks only (i.e. until the unionist marching season began that summer).

\section{Informal petitioned releases}

The re-ignition of Northern Ireland's riots by August 1969 arguably left the UK government with little choice but to grant the Northern Ireland government's request to introduce troops to 'aid the civil power' in an attempt to restore order. With troops came UK government representatives who, despite having little in the way of legal authority ,could from time to time secure informal amnesties for political purposes. This is apparent at a meeting in Derry in August 1969 between James Callaghan, the British Home Secretary, and the Derry Citizens Action Defence Association (DCDA). In this otherwise cordial meeting the DCDA demanded:

[the] release of twenty-one men unjustly detained without charge or trial under the Special Powers Act...If this simple demand for justice is not [acted on] forthwith and these men are not returned to their families on or before Monday we are prepared to mount an intensive campaign of non-cooperation and civil disobedience (Derry Journal, August 29, 1969).

Shortly after the meeting the internees were released. ${ }^{5}$ Though it may not be surprising to see a UK home secretary obtain gratuities from a Northern Ireland government struggling to keep power, an important precedent was nevertheless being established. The release of internees was, at least in part, an attempt by Callaghan to aid the political situation and to sweeten the initial honeymoon period between British troops and the Catholics of Derry's Bogside whose riots had done so much to bring about their deployment.

The very presence of troops, along with continued sectarian provocation on both sides of Northern Ireland's communal divide however ended this initial 'honeymoon' period by the summer of 1970. The increasing number of young rioters being arrested meant that six-month 
mandatory sentences were soon being handed out for commonplace rioting by the end of August. In this context, we see the first informal amnesties being granted by resident British officials for ad hoc political gain. The sheer numbers involved put pressure on the province's tiny judicial system and the Royal Ulster Constabulary (RUC), along with the British government in Northern Ireland, were subject to a barrage of attempts to plead and petition cases of arrest and imprisonment. In this time, there is evidence that some petitioning was effective. Later, Bishop of Derry Edward Daly (then a curate with responsibility for Derry's Bogside) recalled in an interview that:

Every Monday morning there was a flood of telephone calls. First of all, the problem was where they were being held, Armagh, Belfast, Derry. That they'd done nothing wrong (everybody had done nothing wrong of course) ... I went to the police very often. The police sometimes treated you with disdain. But when the Northern Ireland Office came into being there was always someone in the NIO who you could contact. Someone to do with the security minister or someone, and that was the channel I remember going through. There was a procedure (Interview with Bishop Edward Daly, 30 March 2010).

Indeed, there is more evidence of the ability of the British officials to obtain the release of suspects from detention. Cardinal William Conway, the Catholic Primate of All-Ireland and Archbishop of Armagh was a contact courted by successive UK Representatives to Northern Ireland between the 1969 deployment of troops and the 1972 application of Direct Rule from London. Conway was considered a person of influence by the British and an important gauge of Catholic opinion and was, on occasion, supplied with confidential material relating to Britain's relationship with the Vatican. ${ }^{6}$ The cardinal was regularly invited to dine with the UK Representative at the appropriately named Conway Hotel in Belfast during this time and the relationship with the UK Representative bordered on the cosy. ${ }^{7}$ In September 1970 Conway received word that four boys in nearby Portadown had been arrested, convicted and imprisoned for the mandatory six months at St Patrick's Training School (an approved industrial school in Belfast run by the Catholic, De La Salle Order). The brothers there had 
reported that these new boys were 'too good for here' and Conway had also been told that the boys' parents were all 'good people' by their own parish priest. ${ }^{8}$ When Conway raised the issue, Burroughs responded with a letter that barely concealed his ability to pull levers in matters like this. He advised the cardinal that upon speaking with the new RUC Chief Constable Graham Shillington ('who will do whatever he can even if it means bending the regulations a bit') that a formal petition should be made to the Ministry of Home Affairs 'as rapidly as possible. ${ }^{9}$ Within a week the boys were released and the priest who had initially raised the matter with Conway wrote back, reassuring him that 'Nobody knows I approached you' and that no one knew 'what had brought about their speedy release.' ${ }^{10}$ Conway replied only 'better say nothing about it.'11

\section{Internment and detention without trial}

Despite the niceties, the security situation continued to deteriorate in 1971 and collapsed almost entirely with the introduction of internment without trial for IRA suspects that August. The violence continued throughout the winter and spring of 1971-72 and the UK Representative was superseded by the Secretary of State for Northern Ireland when in March 1972 direct rule was imposed, and the Northern Ireland government abolished. Internment was undoubtedly a policy that was determined solely to target Irish republicans. This was despite the fact that loyalist paramilitaries were clearly on the security forces' radar. As early as May 1970 the RUC Special Branch, in a series of papers, had advised the Stormont Cabinet on the implications of any future internment operation, which included the recommendation that 62 loyalists would need to be interned. ${ }^{12}$ However all requests for internment to include loyalists were ignored and the one-sided approach of the early months of the policy from August 1971 therefore only served to alienate the wider Catholic and nationalist population of Northern Ireland. ${ }^{13}$ Of the 342 arrested on 9 August, 116 were 
released within 48 hours and the later Diplock report concluded that those arrested included retired republicans, trade unionists, civil rights campaigners, a drunken man picked up at a bus stop and several cases of mistaken identity. ${ }^{14}$ Within a week the PIRA's Chief of Staff Joe Cahill was able to claim at a press conference in West Belfast that a total of only 30 IRA men had in fact been interned. ${ }^{15}$

The lack of public confidence in internment orders meant that they were constantly being challenged both publicly and privately with scores of letters from families, politicians, priests and employers flooding (initially) the office of the Northern Ireland Prime Minister, Brian Faulkner, whose personal responsibility included the review of all internment cases. When the Northern Ireland government was proroguedin March 1972, this responsibility was to fall to William Whitelaw, as the new Northern Ireland Secretary, and British government cabinet minister.

Like Faulkner, Whitelaw could both release and detain whoever he saw fit under the emergency powers granted by Northern Ireland's Special Powers Act. However, unlike Faulkner, Whitelaw felt 'too many were interned' ${ }^{16}$ and viewed releasing those whose detentions 'were clearly not justified on grounds of violence' ${ }^{17}$ as an opportunity to encourage the minority Catholic community into reengagement with the political process that had stalled when internment was introduced. Reassuring the Social Democratic and Labour Party (SDLP), the largest constitutional nationalist party, of his benevolence was essential to Whitelaw's strategy and he later wrote 'it must be remembered that [the SDLP] were engaged in a struggle for support within the Catholic community with the Provisional IRA ... I needed to encourage the SDLP to build up their strength and their cooperation with the government and the security forces.' 18 
Clear evidence of the success of this strategy was evident in April 1972 with the Irish News reporting 'The unconditional release of seventy-three internees and detainees, and the decision to stop using the Maidstone [HMS] as a prison ship, was welcomed in non-Unionist circles yesterday.' Bonfires were lit across Northern Ireland in celebrating the releases (Irish News, April 8, 1972). The releases were applauded by the SDLP and the party began to change its position on internment. ${ }^{19}$ It no longer insisted upon its immediate end before it would discuss a political settlement. However, while Whitelaw may have released around 700 internees between March 1972 and December 1973, he also interned/detained around 350. Internment was not a revolving door but, given the numbers, discretion was certainly possible. For Whitelaw, who had been publicly opposed to the measure prior to his appointment, there remained many reasons beyond mere guilt or innocence as to why internees might be released and, while in November 1972 Whitelaw had replaced executive 'internment' with 'detention' presided over by a tribunal ${ }^{20}$ he still retained ultimate control over the entire policy if he chose to use it. ${ }^{21}$ Though Whitelaw contended that he studied the individual cases 'with great care', 22 it is also clear that political factors were highly influential in determining the speed of releases and arrests.

In 1986, RJ Spjut, at the University of Kent, summarised the factors involved in the release of Northern Ireland's internees. Spjut demonstrated that the quality of evidence against an individual was less important in practice than the effect their release would have on unionists, the Provisional IRA and moderate nationalists. ${ }^{23}$ A number of political factors therefore affected the rate that internees were released from their detention. The influence of these political factors was also not lost on the Ministry of Defence with one memo stating in March 1972 that not all internees were considered to be 'hard-core' paramilitaries. Indeed $25 \%$ of the detainees were considered to be in the category of least dangerous. They 'could be progressively released if political considerations made this desirable and provided that the 
political initiative was not followed by a major setback.' ${ }^{24}$ Furthermore, their early or sudden release served to taint former low-level internees with the suspicion that they had somehow cooperated or divulged what information they had, making them relatively useless in the eyes of the IRA for future operations. ${ }^{25}$

The increase in releases in December 1973 was therefore part of a wider strategy of attempting coax the SDLP into concessions at Whitelaw's Sunningdale conference and the increased use of Interim Custody Orders (ICOs) in April 1974 can be seen as an attempt to maintain mainstream unionist support. ${ }^{26}$ The detention of loyalists for the first time in February 1973 can also be seen in terms of Whitelaw's efforts to bring the SDLP into political talks. Thus, the main criteria for release was to benefit the political talks' aim of ending the violence. With the Irish government, the moderate nationalist SDLP as well as Sinn Féin and the Provisional IRA all campaigning for internment to end, the British timed the release of internees in tranches designed to appeal to one or more of these parties at particular moments. Too slow and those who sought the releases would stall negotiations, too fast and unionists would be upset that security was not being taken seriously. The system could also work in reverse, and from November 1972 Whitelaw actually began increasing the numbers interned after the SDLP entered talks (though the increase is more often assumed to have coincided with the collapse of the IRA's 1972 ceasefire (See Appendix 1).

The accusation that republican internees were somehow hostages to the political negotiations is proven circumstantially when one considers the imbalance with which internment was applied though arguably these were as much as hostages for the main constitutional nationalist party, the SDLP, as they were for the Provisional IRA. Still, internment offered the UK government bargaining leverage that could increase their influence over Northern Ireland's nationalist and Catholic minority and if power is the ability to affect the behaviour 
of people, then internment gave the Secretary of State a significant amount of it. Whatever the concerns Britain had regarding the one-sided nature Faulkner's policies, successive British Secretaries of State did little to redress this imbalance. From 1969 to 1975 (the period before and throughout internment) deaths caused by paramilitaries in Northern Ireland totalled 1,245. Republicans had killed 778 people (62.5\%) and loyalists $467(37.5 \%) .{ }^{27}$ Of the 1,981 persons interned however, only 107 (5\%) were loyalists. ${ }^{28}$ Using the 1961 census to estimate the numbers of Catholic and Protestant men aged 15-49 in 1971, we can say that internment was used against approximately one in every 152 Catholics males in this age group but only one in every 2,719 Protestant males of the same age. ${ }^{29}$ It was introduced in 1971 against republicans after around 80 people had been killed by these paramilitaries, but against loyalists in 1973 after they had killed over $139 .{ }^{30}$

The bias in favour of loyalist paramilitaries is in fact so great in fact, that until February 1973 it amounted to an amnesty in its own right. Whitelaw himself was briefed on the policy in December 1972:

[t]his policy does not therefore provide for the arrest of Protestants or other nonProvisional terrorists except with the object of bringing a criminal charge. Protestants, are not, as the policy stands, arrested with a view to their being made subject of Interim Custody Orders (ICOs) and brought before the commissioners...Ministers have judged that the time is not at the moment ripe for an extension of the arrest policy in respect of Protestants. ${ }^{31}$

This was despite, around the same time, Whitelaw admitting that 'From some points of view the Protestant extremist factions now presented a more serious threat than the IRA, particularly as regards their gross intimidation of Roman Catholics in isolated areas. ${ }^{, 32}$ The introduction of internment for suspected loyalist paramilitaries began therefore only because the contradiction had become too great to ignore and the bias of the internment policy was symptomatic of the narrow view of the Troubles in Northern Ireland held by a number of its key actors. Perhaps unsurprisingly for the Provisional IRA, this was a war between them and Britain's security forces ${ }^{33}$ but this view was mirrored more often than one 
might expect on the British side. In a sense, soldiers deployed to Northern Ireland were required to create of a certain degree of otherness as a survival mechanism and this would undoubtedly simplify their understanding of the conflict ${ }^{34}$ particularly when loyalist paramilitaries were rarely a threat to their own safety. Much further up however the IRA was (and remains) 'a synonym for all terrorists involved in the Northern Ireland conflict' ${ }^{\text {'35 and }}$ intelligence and security officials regularly reduced 'the grand narrative of counterterrorism in the Troubles to Britain's doughty battle against the PIRA' ${ }^{36}$ The IRA were therefore targeted for internment above and beyond loyalist paramilitaries because of their particular threat to the forces of the state, rather than to law and order more generally. So long as other concerns regarding a possible Protestant backlash if loyalists were targeted for internment remained, they were not at risk of the being subjected to this policy. However, internment only served to objectively increase the general disorder the state faced, fuelling the anger that increased violent activity and paramilitary recruitment on all sides, thereby necessitating only more internment. The effectiveness of internment therefore as a counter insurgency weapon, was highly questionable.

\section{Amnesty and the IRA's 1972 ceasefire}

Whilst Whitelaw (Secretary of State 1972-73), and later Merlyn Rees (1974-76) consistently denied making hostages of republican internees, their explanations of how releases worked repeatedly refers to their having to 'take into account the existing situation in deciding on the speed at which to release them. ${ }^{37}$ Detainees were therefore not being released solely on the merits of each case and a certain degree of leeway was given to the Secretary of State. Whitelaw noted that his efforts, including the release of hundreds of internees, were appreciated in the Catholic community and 'gave me increasing support for tougher security action.' ${ }^{38}$ His successor Rees, in his tape-recorded diary, connected releases with pressure from the SDLP's Austin Currie, Paddy Devlin, Gerry Fitt and John Hume along with the 
Bishop of Derry Edward Daly. ${ }^{39}$ Differences of opinion are apparent among these Nationalist and Catholic representatives. With the SDLP in particular having little in the way of agreed policy in terms of releases despite being in regular contact with the Secretary of State. In early February 1975 two unnamed SDLP representatives even asked PUS Frank Cooper 'you are surely not going to release all the Prov. IRA [?]...' to which Rees determined, 'Of course [the SDLP] want them out... but of course they are able to do this because [the SDLP] have no responsibility. ${ }^{40}$ Rees understood that emptying in internment huts enmasse was not in the SDLP's best interests even if they publicly they could never admit this.

Evidence of a direct trade of internees with the IRA for the purpose benefitting political talks is difficult to see as virtually all the individual internment files remain classified under an 80 year rule. However, probably the clearest example of a prisoner being released in order to accommodate a republican ceasefire is the case of 23-year-old Gerry Adams in June 1972. The ceasefire was largely a republican initiative with initial arrangements made by the SDLP's John Hume and Paddy Devlin who served as go-betweens and attending three progressively more accommodating meetings with the Secretary of State between 15 and 19 June 1972. At these meetings it was agreed that 'Mr Gerald [sic] Adams' would be released from detention (not yet internment, his papers had not been processed) and that 'Special Category' status would be extended to convicted IRA prisoners so they could be afforded the same privileges as the internees. ${ }^{41}$ Whitelaw demurred on both issues, releasing Adams into the custody of Devlin so that talks could begin and granting the IRA prisoners the right to wear their own clothes 'and perhaps receive additional letters and visits.' However, despite it leading to better conditions in prison for the IRA this would not be called 'political status' rather 'Special Category Status'. ${ }^{42}$. Despite this Whitelaw insisted that 'I have made it perfectly clear that the status of political prisoner is not being granted, What has been granted is similar to the facilities provided in the Parkhurst and Leicester wings in this country., 43 
The issue of ending internment more widely was also on the table right from the preliminary discussions with the SDLP. On 15 June 1972, Hume and Devlin had argued that ending internment would put such pressure on the PIRA (following a permanent ceasefire announcement by their rivals the Official IRA on 29 May) and that 'it was a risk worth taking. ${ }^{44}$ The Secretary of State responded that 'If there was a genuine end of terrorism, even for a limited period there would be a genuine response from the government... he did not rule out the ending of internment in these circumstances. ${ }^{45}$

Whitelaw went further on 19 June stating that an end to internment would 'quickly arise' should there be a ceasefire though for 'presentational reasons it might be necessary for some of the internees to be detained and charged in the normal way. ${ }^{46}$ With these words, Whitelaw was outlining the limitations of his political power when it came to the actual amnesty; he could not risk a backlash from unionists by releasing all those interned if there would ultimately be a legal case against them. Releases therefore had to be done surreptitiously and with the least possible publicity. Whereas Adams could be released, special treatment provided to those in prison for terrorist offenses and even internment without trial ended, the suspension of criminal law (or worse the establishment of precedents that could have a longer-term impact) was not an option at this stage. There would therefore be no amnesty as such, though internment without trial would end quickly in the event of an IRA ceasefire.

However, if amnesty could not be granted publicly there were still a variety of options in a range of areas that could grant roughly the same thing. Internal discussions prior to the IRA's 1972 ceasefire reveal less ambivalence toward using the term 'amnesty' though it was not a term used publicly. It was quite sensible for example to acknowledge that if IRA members were 'lifted' during the ceasefire there might be consequences. Kelvin White, the influential head of the Foreign and Commonwealth Office's Republic of Ireland Department, noted that 
'there would in effect, be an amnesty for those IRA men who had managed to evade capture until the date of the truce and who, if they had been captured could only have been detained under the Special Powers Act. ${ }^{47}$ The NIO, RUC and British Army all also assumed that the release of remaining internees would occur and instructions were circulated to the effect that, during a ceasefire, they would not pursue individuals for the purposes of internment. ${ }^{48}$ Indeed some months earlier the army had outlined that although it was against ending internment it was 'prepared to see greater selectivity. We quite appreciate that the political impact would be greater if it could be announced that, along with accelerating the release of those interned, there would be no further internment orders. ${ }^{49}$ Additionally in late 1973 the NIO outlined its awareness of the political sensitivities surrounding internment arrests with Frank Cooper informing James Flanagan, RUC Chief Constable, in relation to possible loyalist detentions 'There will however still be a small number of cases where arrest might have political implications and on which we should consult the Secretary of State first- just as we would for certain top IRA men.' 50

Importantly White's suggestions went further, proposing that, should the ceasefire hold (and the amnesty alongside it) for any length of time, the amnesty would surely also need to apply somehow to those who were not simply suspected members of the IRA but those who could actually be charged with terror offenses. Acknowledging how the prosecution of existing warrants might be seen by the IRA, White offered the solution of a list, made public, of those for whom there was sufficient evidence to charge with serious offenses carried out before the ceasefire. This list contained the proviso that 'the evidence available was insufficient to warrant proceedings against anyone "save those listed above" and that the RUC had therefore closed all other files. ${ }^{51}$ The list, containing the names of 107 men for whom sufficient evidence was available for prosecution ${ }^{52}$ was circulated on 5 July following the instructions 
that arrests should only be made for specific criminal acts, and no longer for interrogation or internment purposes.

In any event the 1972 IRA ceasefire collapsed only days later (9 July); long before an end to internment was considered, or even before the 'wanted' list was circulated publicly. And, whilst violence returned, it is clear that some key lessons were learned with regard to the handling of nascent peace talks that would prove useful especially following the collapse of the public/political Sunningdale agreement in $1974 .{ }^{53}$

\section{The IRA's 1975 ceasefire, Laneside and amnesty}

The NIO's officials at their Laneside offices (arguably the vestigial Office of the UK Representative that including secondments from both MI6 and the diplomatic service) began utilising the authority of the NIO for political gain in their talks with both loyalist and republican representatives in 1974 . At these talks, individual cases were brought up, with the loyalist UDA often seeking forms of patronage in exchange for cooperation in other matters. Their requests were often reasonable - they asked for direct buses from Belfast for visitors to their internees in Long Kesh prison camp or for the release of 'goodies' from internment that could help with their political organisation but who were not involved in the paramilitary side. There is some evidence to suggest these requests were acted upon but no evidence proving much overall impact on wider issues. ${ }^{54}$ For one British participant in these talks:

a lot of his work was straight Foreign Office type work. You come across a chap, who tells you we're having terrible trouble in Andersonstown or one thing and another and you are both a recipient of the news and you can also try to resolve matters. Where some local civil servants were under terrific strain and often a chat on the phone would sort things out. I mean it was certainly unprotocolaire (Interview with James Allan (FCO on Secondment to NIO) 18 January 2010).

Central to the work of the officials at Laneside was the attempt to ameliorate the causes of the conflict in Northern Ireland and to demonstrate to the paramilitary groups the efficacy of cooperation with the state's existing democratic structures. Internment had demonstrated that 
peace could not be coerced so secret talks there joined the office's previous functions of entertaining local dignitaries, the press and community representatives in order to both listen and report their positions as well as to explain and persuade to their guests the British government's position.

The election of a Labour government in March 1974 meant that the insistence, following the collapse of the IRA's 1972 ceasefire that Britain would not talk to the IRA began to fall into abeyance despite what the new Secretary of State said at the time. Initial evidence that the IRA were once again seeking a ceasefire and talks came as early as April 1974 when the newly appointed Bishop Edward Daly, alongside John Hume met with the newly appointed junior minister Stan Orme MP in Derry. Daly told Orme he had been approached by a Provisional IRA member who claimed that 'the Provos in Derry were ready for a ceasefire. He further claimed that $90 \%$ of the Provos in Northern Ireland would like to see a ceasefire and only the 'hard men' at the head of the Belfast IRA brigade had any interest in continuing the violence. ${ }^{55}$ Though the NIO was otherwise preoccupied with the collapse of the Sunningdale power sharing executive and the UWC strike for the rest of that spring, leading Provisional republican Seamus Loughran made at least two visits for direct talks at Laneside between July and November 1974 representing the first direct engagements with the British since the 1972 ceasefire had collapsed. ${ }^{56}$

At these talks, Loughran (PIRA's Officer Commanding [OC] Belfast though under Sinn Fein cover $^{57}$ ) was pleasantly surprised by the pleasantries afforded to him by the 1974 cohort at Laneside. He even compared them favourably to the (largely Home Office) group he had met there in 1972 who, Loughran said 'had looked down on me as if I was something that had crawled out of a bog. ${ }^{58}$ Loughran spoke of Sinn Féin's refusal to participate in the political talks so long as internment continued and he brought up individual cases of internment as 
well as his own experience, concluding that it was internment that had 'bred violence' and that the government were using the policy as 'a political weapon'. 59

Loughran's talks, combined with other meetings with Jimmy Drumm and Billy McKee (PIRA Vice OC Belfast ${ }^{60}$ ) as well as the all-important talks between Laneside's Michael Oatley, Derry businessman Brendan Duddy and Sinn Féin's Ruairí Ó Brádaigh laid the foundations for a ceasefire initiative, with the PIRA conveniently supplying evidence of their willingness to call a ceasefire. ${ }^{61}$ It was through this Duddy channel that over Christmas and New Year 1974/75 the IRA decided to extend their ceasefire and a bilateral truce agreement was hammered out. Importantly, this truce agreement granted IRA members several indemnities that together can be considered a temporary amnesty.

The ceasefire agreement or 'Terms for a bilateral truce' contained twelve items, allowing for freedom of movement, freedom from arrest, raids, harassment, screening and photographing of all members of the republican movement. ${ }^{62}$ It also contained a general agreement for the British not to take advantage of the ceasefire to reintroduce the RUC and the locally-raised Ulster Defence Regiment (UDR) to 'designated' (presumably republican) areas ${ }^{63}$ and an arrangement that troops would be progressively withdrawn to barracks as the truce took hold. ${ }^{64}$ Importantly, however the IRA would be allowed to carry unlicensed and illegal firearms (defined only as concealed short arms) for their own protection through the period of the truce. ${ }^{65}$

\section{Ending internment}

Whilst the truce terms marked the official (if secret) means through which a ceasefire could be determined to be in place, the release of internees (though not mentioned formally) was essential to greasing the wheels of the ceasefire deal. Research published in 2012 by Freddie Cowper-Coles on talks with the IRA has been the most forthright thus far in terms of linking 
releases from internment with IRA demands and the UK's desire for a ceasefire. Importantly Cowper-Coles has linked the preliminary talks with Secretary of State Merlyn Rees' release of 53 internees on 31 December 1974 and the PIRA's Dáithí Ó Conaill's request that 'gestures on internment and on whether [the British] would always remain in Ireland were required' mentioned at the earlier Feakle talks. ${ }^{66}$ Rees' own diaries provide further evidence for this hypothesis, noting on 24 December that, in the context of ending detention 'the Provisional IRA obviously can deliver more than the SDLP and anybody else... ${ }^{67}$ On 8 February he notes his reluctance to continue releases, noting that the four Catholics he released that day 'are evil murderers, but that is the case [sic] we are getting into. ${ }^{96}$

However, there is another explanation for the acceleration of releases during the IRA's 1975 ceasefire. Rees and much of the NIO clearly believed that internment as a policy had not worked, but it was a difficult thing to undo once established. This had been understood as early as November 1971 when a Home Office memo recognised that internment had led to the 'view that HMG in Westminster are prepared to act as a rubber stamp for Mr Faulkner's anti-Catholic measures ${ }^{69}$ and that the increase of violence gave the impression that the IRA were now 'a mass movement instead of a small body using the Catholics for cover... the damage has now been done. ${ }^{70}$ However the memo then went on to state that 'we could not now abandon internment altogether ${ }^{911}$ Therefore, while Rees had continuously stated his opposition to internment when he was shadow secretary for Northern Ireland, once in government he was not opposed to using the internees for political gain. Prior to the 1972 ceasefire Rees even told the commons that:

We on this side have always been concerned about ... internment without trial, and that we support the detention of all those against whom charges are brought... For the rest, taking into account the problems involved, their release would do much to help the forthcoming talks. ${ }^{72}$ 
The forthcoming talks Rees was referring to were with the SDLP however and not the Provisional IRA and by 1975 Rees noted in his diary recordings that he was actually inclined to slow the rate of releases from internment in an attempt to extend the IRA's ceasefire 'by putting the releases... on the slow long finger... their people up in the Maze [prison] do not want the ceasefire ended and, in many respects, this is... what I intended. ${ }^{, 73}$

Another problem in linking releases from internment too closely to the IRA ceasefire were the recommendations for the policy to end coming from a series of the British government's own reports. Not least of which was the Gardiner report, published just days after the IRA's ceasefire announcement but seen and read by Rees in December. ${ }^{74}$

Though Gardiner had indeed recommended ending internment, the report had a significant sting in the tail so far as the IRA were concerned as it also recommended an end to the Special Category Status that IRA inmates (both internees and convicts) had enjoyed since the previous IRA ceasefire in 1972. Furthermore, Gardiner backed the continuation of juryless courts established by the Diplock Report and incorporated into the Emergency Provisions Act in 1973. This was an attempt to increase both the conviction rate and the sentence duration for terrorist offences, setting the ground work for the 'normalisation' policies Rees was to enact and the prison conflict that resulted in the 1980/81 republican hunger strikes.

The Gardiner Committee also sought the extension of terrorist offenses to include recruitment, disguise, the publication of advertisements by illegal organisations and the extension of stop, search and seizure powers of the police. ${ }^{75}$ Gardiner specifically spelled out the danger associated with amnesty in his report, stating that:

It should be made absolutely clear that Special Category Status prisoners can expect no amnesty and will have to serve their sentences. We can see no justification for granting privileges to a large number of criminals convicted of very serious crimes, in many cases murder, merely because they claim political motivation. It supports their view, that society must reject, that their political motivation in some way justifies their crime. ${ }^{76}$ 
Rees supported Gardiner but the truce needed a context that would extend its longevity. And while the longer the ceasefire continued, the more questions would arise with regard to convicted prisoners, unfulfilled arrest warrants and unsolved murder inquiries, the release of internees was therefore something which for Rees was a matter of when rather than if. Seen in this way, the release of internees was an essential part of the ceasefire arrangements along with the amnesty on IRA membership and movement, but they were also an essential part of moves toward normalisation/criminalisation/ulsterisation and the two (thankfully for Rees) were not contradictory. In this respect, the aim underlying the release of internees was to positively reinforce the burgeoning peace process in a way that would publicly as well as privately isolate irreconcilables and establish an excuse to clamp down even more firmly should the ceasefire collapse. The IRA could believe they were getting amnesty for internees (and would if the ceasefire continued) but the occasion of their release was a part of both a larger policy change and in the context of a constitutional settlement that Rees was also attempting to negotiate among the mainstream political parties at 1975 's Constitutional Convention.

\section{Evaluating arrest/release policies}

Although the introduction of internment in August 1971 was undoubtedly a complete failure, when the British took over the implementation of the measure in 1972 they had quite different aims and operated internment in a different way. As the NIO believed they had only inherited internment they could plausibly argue that they wanted internment to end, albeit in a manner that caused as little political upheaval as possible. Obviously, they did not want to cause a Protestant backlash and on the whole, they achieved this. Even when the internment of loyalists was introduced in February 1973 the resulting Loyalist Association of Workers strike was short-lived and lacked widespread support. ${ }^{77}$ Indeed, the only major Protestant 
backlash of this period, in May 1974, was in response to the Sunningdale Agreement and had little connection to the internment issue. As Whitelaw outlined in June 1972, 'a principal object' of British policy following Direct Rule was the detachment of 'moderate Roman Catholics from supporting the IRA'.$^{78}$ Indeed, immediately after the introduction of internment in 1971 Edward Heath had highlighted the 'need to isolate the more extreme elements. ${ }^{, 79}$ Whilst it took several years, they were arguably successful in achieving this specific objective and their careful manipulation of internment arrests and releases made a crucial contribution to this success. The tactic of decreasing arrests and increasing releases of republicans simultaneously can be observed when these figures are examined in detail. This approach aided the further isolation of moderate nationalists from more extreme republican elements and thereby helped political progress elsewhere. Indeed, just such a scenario occurred immediately after the implementation of Direct Rule and periodically during the development of talks leading to the Sunningdale Agreement. ${ }^{80}$ Arguably the most concrete proof of the success of the British policy was the fact that they were able to introduce their 'criminalisation' policy in 1975 without many broad-based nationalist protests or a dramatic increase in the levels of violence as had occurred in 1971 when internment had been introduced.

\section{Conclusions}

In Irish republican historiography, the IRA leadership of 1975 came to be seen as dupes of the British in believing that the release of internees was the beginning of a British policy of disengagement when it was in fact only the start of a wider criminalisation programme. For Bishop and Mallie 'The leadership of the IRA seemed to be mesmerised by this [release] process and oblivious to the importance of the parallel operation which was taking place. ${ }^{, 81}$ Kieran Conway has rightly however stated that 'it is not at all clear that they were that clever, 
or our negotiators that stupid.' ${ }^{82}$ One needs to move away from the dichotomous mind-set of a war between two parties in Northern Ireland in order to understand the multidimensional complexity of releasing detainees and ending internment. In so doing one can see pressures to both detain and release coming from across the political spectrum. Moreover, whilst the amnesties agreed in the 1975 truce agreement were the result of bilateral talks with the IRA, the internment issue was at the centre of both the political and legal changes that were already being formulated elsewhere.

Internment undoubtedly targeted Irish republicans disproportionately to loyalists in Northern Ireland. This was partly because Britain, as the Northern Ireland government before them, considered republican terrorism the only threat worth addressing. This however inadvertently undermined wider Catholic support for British policy and bolstered support and membership of the IRA. Internment had plainly failed to constrict the IRA and even served to change the nature of the conflict by widening its scope into the hinterlands, border and market towns ${ }^{83}$ making it more difficult (and expensive) to combat. Internees came to be treated as hostages, both for IRA ceasefires, as well as for wider cooperation with nationalism and the SDLP. Internees could not simply all be released (as this would create a Protestant backlash) but they could be gradually traded over time. Though the British recognised that internment had to go as early as November 1971, by 1975 it was additionally clear that there was no room for detention without trial in the new security strategy for Northern Ireland. The question, then, was about how quickly this could happen and how it could be done in a way that minimised the damage and maximised the potential benefit for Britain. By timing arrests and releases in the way they did from 1972 onwards, through a careful use of the available intelligence, the British government managed to present the IRA with what looked very much like an amnesty, but which also served Britain's purposes of strengthening the criminal justice 
system in the longer term and galvanising nationalist support for a political process that marginalised Irish republicans. 


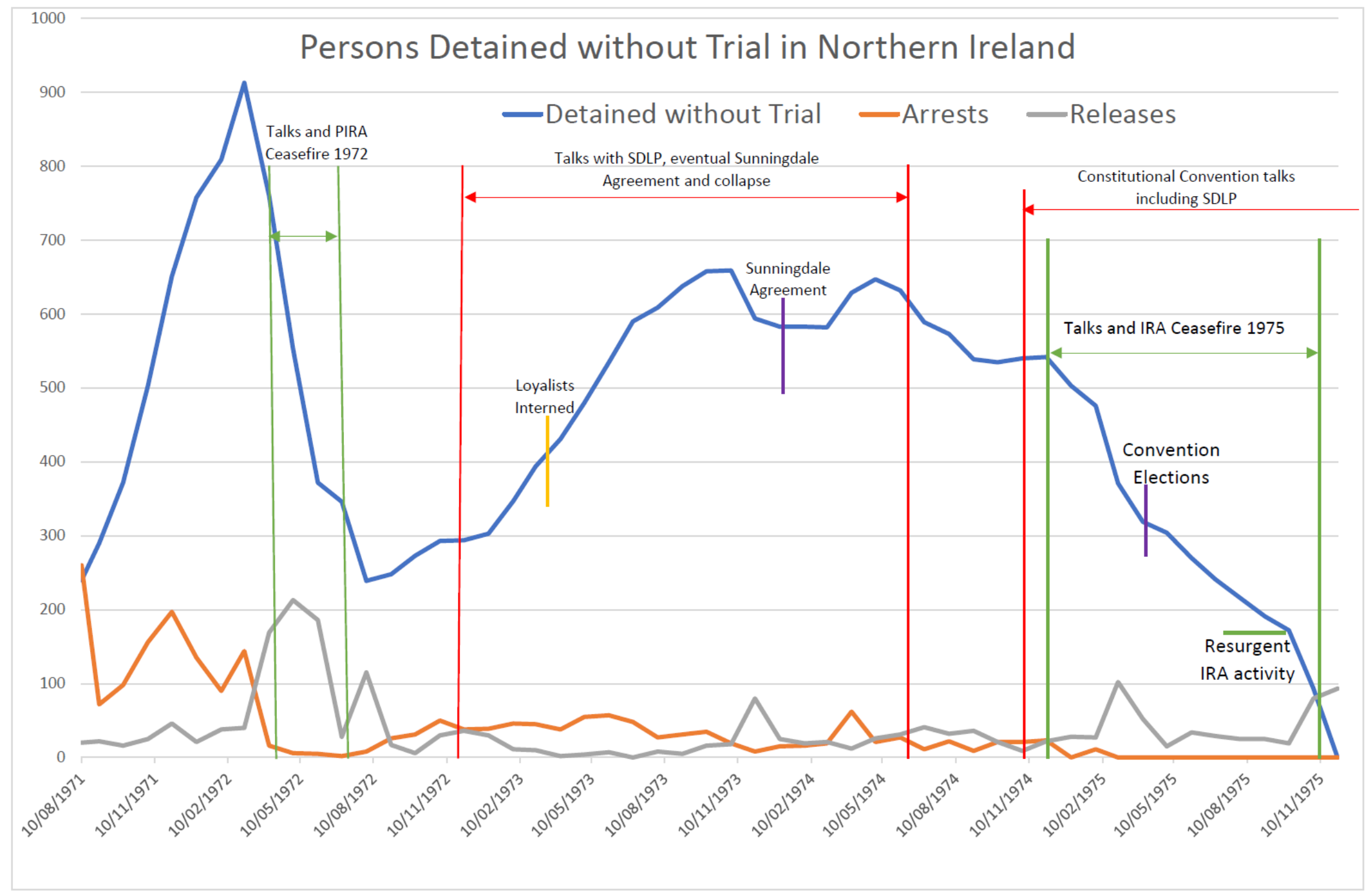


Notes

1. English, Armed Struggle, 123-4.

2. McEvoy, Briefing Paper Amnesties, 4.

3. McEvoy et al., Dealing with the Past, 6.

4. Patterson and Kaufmann, Unionism and Orangeism, 90.

5. O' Dochartaigh, From Civil Rights to Armalites, 119.

6. Burroughs to Conway 5 June 1970, enclosing confidential record of conversation between Foreign Secretary and Pope Paul VI, 25 May 1970, 24/6, Papers of Cardinal William Conway, Cardinal Tomás Ó Fíaích Library and Archive, Armagh.

7. Conway was once sent a pair of socks from Harrods in the post from UKREP Ronnie Burroughs following a dinner earlier in the week. Conway replied thanking Burroughs for the 'enclosures' and remarked that 'the size is right, the colour almost right.' Conway to Burroughs 1 September 1970, 24/6, Conway Papers, Armagh.

8. Fr John Bradley to Conway 18 September 1970, 24/6, Conway Papers, Armagh.

9. Burroughs to Conway 25 September 1970, 24/6, Conway Papers, Armagh.

10. Bradley to Conway 18 October 1970, 24/6, Conway Papers, Armagh.

11. Ibid.

12. Letter from RUC Special Branch, First paper on detention and internment under Civil Authorities (Special Powers) Acts, 21 May 1970; second paper, 1 July 1970; third paper, 6 August 1970, Cabinet Conclusions, $\mathrm{CAB} / 9 \mathrm{~B} / 83 / 6$, Public Record Office of Northern Ireland (PRONI).

13. Sanders, "Northern Ireland", 243.

14. McCleery, "Debunking the Myths", 416; Diplock 1972 para 32.

15. Anderson, Joe Cahill, 230.

16. Whitelaw, The Whitelaw memoirs, 78.

17. Ibid., 92.

18. Ibid., 93.

19. Spjut, "Internment and Detention", 720.

20. Ibid., 719

21. Lowry, "Internment: Detention Without Trial", 293-294.

22. Whitelaw, Memoirs, 93.

23. Spjut, "Internment and Detention", 725-735.

24. R.A. Curtis (MOD) to P.L Gregson (PM's Office), 'Northern Ireland: Internment', 6 March 1972, DEFE/24/1215, The National Archives Kew (TNA).

25. McCleery, Operation Demetrius, 85.

26. Ibid.

27. Sutton, Index of Deaths available at http://cain.ulst.ac.uk.

28. Melaugh, Internment - Summary of Main Events available at https://cain.ulster.ac.uk/events/intern/sum.htm

29. Northern Ireland Census 1961, General Report, 23-24.; Sutton, Index of Deaths.

30. Sutton, Index of Deaths

31. 'Arrest policy for Protestants': Memo by Major G. Bulloch, for GOC, for SOS morning meeting, 11 December 1972, PRONI, CAB/9/G/27/6.

32. Cabinet Conclusions, 02 November 1972, CAB/128/50/49, TNA.

33. Seamus Loughran told a British official categorically 'Our fight is with the British' Meeting with Seamus Loughran, 9 July 1974, FCO 87/342, TNA; See also English, Armed Struggle; 120-147.

34. Burke, An Army of Tribes, 215-217.

35. O’Halpin, "British Intelligence", 163.

36. Ibid., 186

37. Spjut, "Internment and Detention", 733.

38. Whitelaw, Memoirs, 102

39. Rees Diary 8 Feb 1975 Rees 1/6, Papers of Merlyn Rees, London School of Economics.

40. Note of meeting between the Secretary of State and SDLP representatives (Mr Hume and Mr Devlin), 19 June 1972, PREM 15/1009, UK National Archives (TNA) and Patrick Bishop \& Eamonn Mallie, The Provisional I.R.A. (Corgi, London, 1988); 225. 
41. Note of meeting between the Secretary of State and SDLP representatives (Mr Hume and Mr Devlin) 18 June 1972, PREM 15/1009, TNA.

42. Conway, Southside Provisional, 107-108.

43. House of Commons Debates, vol. 839, 19 June 1972, c. 36.

44. Note of a meeting between the Secretary of State and Mr Hume and Mr Devlin, 15 June 1972, PREM 15/1009, TNA.

45. Ibid.

46. Note of meeting between the Secretary of State and SDLP representatives (Mr Hume and Mr Devlin), 19 June 1972, PREM 15/1009, TNA.

47. Kelvin White (FCO) to Denis Trevelyan (NIO), 21 June 1972, CJ 4/251, TNA.

48. William Nield to William Whitelaw (attached note 'Security Forces reactions to a ceasefire'), 26 June 1972, CJ 4/251, TNA.

49. R.A. Curtis (MOD) to P.L. Gregson, Secret Perimeter, 16 February 1972, DEFE 24/12/15, TNA.

50. Frank Cooper (NIO) to James Flanagan (CC RUC), 13 November 1973, CJ4/724, TNA.

51. Kelvin White (FCO) to Denis Trevelyan (NIO), 21 June 1972, CJ 4/251, TNA.

52. Persons sought for interview [lists] and RUC HQ to Divisional Commanders All Special Branch Offices, [undated], CJ 4/251, TNA.

53. Craig, "Monitoring the Peace?", 307-319.

54. Craig, "Laneside, Then Left a Bit?", 307-308.

55. Note of informal meeting with Bishop Edward Daly and John Hume in Londonderry, 13 April 1974, FCO 87/341, TNA.

56. Meeting with Seamus Loughran, 9 July 1974, FCO 87/342, TNA.

57. Conway, Southside Provisional, 172; Rees Diary, 27.

58. Meeting with Seamus Loughran, 9 July 1974, and Note for the Record Mr Seamus Loughran, 18 July 1974, FCO 87/342, TNA.

59. Ibid.

60. Conway, Southside Provisional, 172.

61. Craig, "From Backdoors and Back Lanes", 97-100.

62. Terms for a bilateral truce, §1-5, PREM 16/521, TNA,

63. Ibid., §8.

64. Ibid., $\$ 10$.

65. Ibid., §6.

66. Cowper-Coles, "Anxious for peace", 228-229.

67. Rees Diary, 26.

68. Rees Diary, 20.

69. Possible changes in Internment procedure, Home Office Memo, 4 November 1971, CJ 4/1333, TNA.

70. Ibid.

71. Ibid.

72. House of Commons Debates, 3 August 1972, vol 842. cc933.

73. Rees Diary, 33.

74. Rees, Northern Ireland, 211.

75. Gardiner Report 1975, Cmnd 5847, §20-24; 52-53.

76. Ibid; 34.

77. Bew and Gillespie, Northern Ireland, 58-60.

78. Cabinet Conclusions, 15 June 1972, CAB/128/48, TNA.

79. Cabinet Conclusions of meeting held at Chequers, 19 August 1971, CAB/A/1607/19, PRONI.

80. See Appendix 1.

81. Bishop \& Mallie, The Provisional I.R.A., 277.

82. Conway, Southside Provisional, 193.

83. McCleery, Operation Demetrius, 148-165.

84. Figures from Spjut, "Internment and Detention”, 712-740. 


\section{Bibliography}

Anderson, Brendan. Joe Cahill: A Life in the IRA. Dublin: O'Brien Press, 2002.

Bew, Paul, and Gordon Gillespie. Northern Ireland: A Chronology of the Troubles 1968-1999. Dublin: Gill and Macmillan, 1999.

Bishop, Patrick, and Eamonn Mallie. The Provisional I.R.A. London: Corgi, 1988.

Burke, Edward. An Army of Tribes: British Army Cohesion, Deviancy and Murder in Northern Ireland. Liverpool: Liverpool University Press, 2018.

Conway, Kieran. Southside Provisional: From Freedom Fighter to the Four Courts. Blackrock: Orpen Press, 2014.

Cowper-Coles, Freddie. "Anxious for Peace: The Provisional IRA in Dialogue with the British Government, 1972-75." Irish Studies Review 20, no. 3 (2012): 223-242.

DOI: 10.1080/09670882.2012.697698.

Craig, Tony. "From Backdoors and Back Lanes to Backchannels: Reappraising British Talks with the Provisional IRA, 1970-1974." Contemporary British History 26, no.1 (2012): 97-117. DOI: 10.1080/13619462.2012.656391.

Craig, Tony. "Laneside, Then Left a Bit? Britain's Secret Political Talks with Loyalist Paramilitaries in Northern Ireland, 1973-197." Irish Political Studies 29, no. 2 (2014): 298-

317.

DOI: $10.1080 / 07907184.2012 .732952$.

Craig, Tony. "Monitoring the Peace?: Northern Ireland's 1975 Ceasefire Incident Centres and the Politicisation of Sinn Féin." Terrorism and Political Violence 26, no. 2 (2014): 307-319. DOI: 10.1080/09546553.2012.711395.

[Diplock Report] Report of the Commission to Consider Legal Procedures to deal with Terrorist Activities in Northern Ireland 1972, Cmnd 5185, Cain Web Service.

Available @ https://cain.ulster.ac.uk/hmso/diplock.htm Accessed 28/03/2019.

English, Richard. Armed Struggle: The History of the IRA. London: Pan Books 2004.

[Gardiner Report] Report of a Committee to Consider, in the Context of Civil Liberties and Human Rights, Measures to Deal with Terrorism in Northern Ireland 1975, Cmnd 5847, House of Commons Parliamentary Papers Online.

Available @ https://parlipapers.proquest.com/parlipapers/docview/t70.d75.1974-

064500 ?accountid=17254 Accessed 28/03/2019.

Lowry, David R. "Internment: Detention Without Trial in Northern Ireland." Human Rights 5, no.3 (1976): 261-331.

www.jstor.org/stable/27879033

Melaugh, Martin, Internment - Summary of Main Events Available @

https://cain.ulster.ac.uk/events/intern/sum.htm

McCleery, Martin. "Debunking the Myths of Operation Demetrius: The Introduction of Internment in Northern Ireland in 1971." Irish Political Studies 27, no.3 (2012): 411-430.

DOI: 10.1080/07907184.2011.636804.

McCleery, Martin. Operation Demetrius and its Aftermath: A New History of the Use of Internment Without Trial in Northern Ireland, 1971-75. Manchester: Manchester University Press, 2015.

McEvoy, Kieran. Briefing Paper Amnesties, Prosecutions \& the Rule of Law in Northern Ireland, UK Defence Select Committee, 7 March 2017. 
Available@ https://amnesties-prosecution-public-interest.co.uk/themainevent/wpcontent/uploads/2018/05/Amnesties-Prosecutions-and-the-Rule-of-Law-in-NorthernIreland-7-March-2017-final-Briefing-Document-for-the-Defence-Select-Committee.pdf Accessed on 27/03/2019.

McEvoy, Kieran, Louise Mallinder, Gordon Anthony and Luke Moffett. Dealing with the Past in Northern Ireland: Amnesties, Prosecutions and the Public Interest, Written Submission to Dr Richard Haass, Dr Meghan O'Sullivan and the Panel of Parties in the NI Executive (2013). Available @ https://blogs.qub.ac.uk/amnesties/files/2013/11/Amnesties-Prosecutions-andPublic-Interest-Submission-to-Haass-talks.pdf Accessed on 13/12/2018.

Northern Ireland Census 1961, General Report.

Available @ https://www.nisra.gov.uk/sites/nisra.gov.uk/files/publications/1961-censusgeneral-report.pdf Accessed on 05/01/2019.

O' Dochartaigh, Niall. From Civil Rights to Armalites: Derry and the Birth of the Irish Troubles. New York: Palgrave Macmillan, 2005.

O'Halpin, Eunan. "British Intelligence, PIRA, and the Early Years of the Northern Ireland Crisis." in The Image of the Enemy: Intelligence Analysis of Adversaries Since 1945, edited by Paul Maddrell, 162-189. Washington, DC: Georgetown University Press, 2015.

Patterson, Henry, and Eric P. Kaufmann. Unionism and Orangeism in Northern Ireland Since 1945: The Decline of the Loyal Family. Manchester: Manchester University Press 2007. Rees, Merlyn. Northern Ireland: A Personal Perspective. London: Methuen, 1985. Sanders, Andrew. "Northern Ireland: The Intelligence War 1969-75." British Journal of Politics and International Relations 13, no.2 (2011): 230-248.

DOI: 10.1111/j.1467-856X.2010.00416.x.

Spjut, R. J. "Internment and Detention Without Trial in Northern Ireland 1971-1975: Ministerial Policy and Practice." The Modern Law Review 49, no.6 (1986): 712-740. Sutton, Malcolm. An Index of Deaths From the Conflict in Northern Ireland. Available @ https://cain.ulster.ac.uk/sutton/updates.html Accessed 11/09/2018. Whitelaw, William. The Whitelaw Memoirs. London: Aurum, 1989. 